\title{
Proust au tournant des siècles, 2. «Marcel Proust» 5, Textes réunis par Bernard Brun et Juliette Hassine
}

\section{Emanuele Kanceff}

\section{(2) OpenEdition}

1 Journals

\section{Edizione digitale}

URL: http://journals.openedition.org/studifrancesi/27972

DOI: 10.4000/studifrancesi.27972

ISSN: 2421-5856

\section{Editore}

Rosenberg \& Sellier

\section{Edizione cartacea}

Data di pubblicazione: 31 décembre 2006

Paginazione: 635

ISSN: 0039-2944

\section{Notizia bibliografica digitale}

Emanuele Kanceff, «Proust au tournant des siècles, 2. «Marcel Proust» 5, Textes réunis par Bernard Brun et Juliette Hassine », Studi Francesi [Online], 150 (L | III) | 2006, online dal 30 novembre 2015, consultato il 08 novembre 2020. URL : http://journals.openedition.org/studifrancesi/27972 ; DOI : https://doi.org/10.4000/studifrancesi.27972

\section{Questo documento è stato generato automaticamente il 8 novembre 2020}

\section{(c) (1)}

Studi Francesi è distribuita con Licenza Creative Commons Attribuzione - Non commerciale - Non opere derivate 4.0 Internazionale. 


\title{
Proust au tournant des siècles, 2. «Marcel Proust» 5, Textes réunis par Bernard Brun et Juliette Hassine
}

\author{
Emanuele Kanceff
}

\section{NOTIZIA}

AA. VV., Proust au tournant des siècles, 2. «Marcel Proust» 5, Textes réunis par Bernard BRUN et Juliette HASSINE, Paris-Caen, Lettres Modernes Minard, 2005, pp. 297.

1 Sostazialmente il volume, che è in buona parte frutto di un convegno tenuto alla BarIlan University, si interroga sul valore del tempo e della storia e sulla funzione dello scrittore, che deve far fronte alla precarietà e ricreare all'infinito una parvenza di perennità. Non essendo possibile un'analisi di ciascun intervento in questa sede, ci limitiamo ad elencare in sintesi i contenuti del ricco volume, che si apre con un avantpropos di Juliette HASSINE e continua con i testi seguenti:

2 Note sur une lettre inédite adressée par Marcel Proust à Léon Blum à l'époque du Banquet, di Ilan GREILSAMMER.

Parte prima: «Sur la lecture».

1. Legrandin: un pastiche de Rousseau?, di Pyra WISE.

2. Le Voyage à Balbec... et en Orient, di David MENDELSON.

3. À rebours, un intertexte de l'épisode de la «petitemadeleine», di Danielle-Claude BÉLANGER.

4. Proust et Mallarmé, di Akio UsHiBA.

5. Gracq et Proust, di Simone GROSSMAN

6. L'Être et le paraître chez Proust et Pirandello, di Jacques MISAN-MONTEFIORE.

7. "Contre Proust" ou le retour du biographique: "À la recherche de Marcel Proust" avec André Maurois, di Judith KAUFFMANN. 
8. Points de rencontre entre Marcel Proust et Smilansky Yizhar, di Noemi SHANI.

Parte seconda: «L'écriture infiinie»

9. Correspondance des arts et intermédialité: figures du désir dans "À la recherche du temps perdu", di Volker ROLOFF.

10. Tableaux désignés, suggérés et cachés dans la "Recherche", di Kazuyoshi YosHIKAWA.

11. Revisiter l'atelier d'Elstir: l'image du cheval dans l"'ekphrasis" du "Port de Carquethuit", par Hiroya SAKАMOTO.

12. La Doctrine proustienne de l'intelligence: une hypothèse intertextuelle, di Alessandro GRILLI.

13. La Monstruosité dans "À la recherche du temps perdu", di Aude LE ROUX-KIEKEN.

14. L'«Andromède masculine»: sources de l'imaginaire homosexuel dans "À la recherche du temps perdu, di Yasué KATO.

4 L'insieme di questi studi offre interessanti prospettive sulla lettura dei testi proustiani, sulla coincidenza tra le arti, sulla letteratura comparata, contribuendo sia allo studio genetico dei testi, sia alla miglior conoscenza dell'intertestualità. Si può solo rimpiangere l'assenza di qualsiasi strumento di sintesi, sia a livello di indici che di apparati bibliografici. 